\title{
Transverse myelitis with Brown-Sèquard syndrome after H1N1 immunization
}

Mielite transversa manifesta por síndrome de Brown-Sèquard após vacinação contra H1N1

Marcelo Adriano da Cunha e Silva Vieira', Carlos Henrique N. Costa², Chrystiany Plácido de B. Vieira², Maria do Amparo S. Cavalcanti², Sebastião P. Ferreira-Filho ${ }^{3}$

A 52-year-old female had acute urinary hesitancy, constipation, crural spastic asymmetric paraparesis and sensory level at T6 (hypopalesthesia left and thermo-algesic hypoesthesia on the right mainly on sacral dermatomes) one week after H1N1-trivalent immunization.

Magnetic resonance imaging showed thoracic intramedullary lesion (Figure) and absence of brain findings. Cerebrospinal fluid was normal including electrophoresis, viral polymerase chain reactions and cultures. HIV-serology, VDRL, and anti-nuclear antibodies were nonreactive.

Brown-Sèquard syndrome commonly results from traumatic or tumor injury and is rarely found in other etiologies ${ }^{1,2}$. Myelitis constitute possible adverse event temporally related to immunization and his notification contribute to post-marketing studies on the safety of immunobiological extensively used in population ${ }^{3}$.
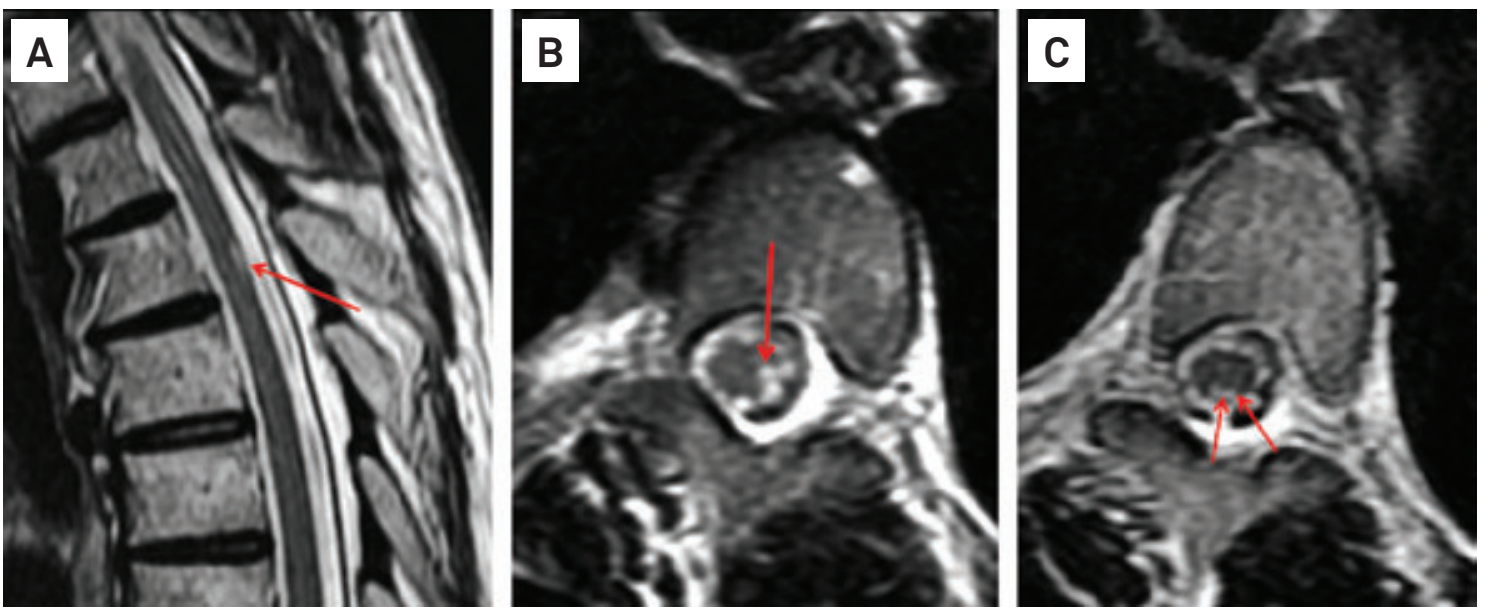

Figure. MRI image sagittal showing T2 hyperintese lesion on the dorsal aspect of the spinal cord at the level of the fourth thoracic vertebra (A); axial MRI showing multiple tiny and T2 hyperintense lesions compromising the left lateral and dorsal aspect of the spinal cord at same level (B and C).

\section{References}

1. Durrant DH, True JM. Spinal cord syndromes and guide to neurological levels. In: Durrant DH, True JM (Eds). Myelopathy, radiculopathy and peripheral entrapment syndromes. Washington, DC: CRC Press, 2002:139-157.

2. Sheerin F, Collison K, Quaghebeur G. Magnetic resonance imaging of acute intramedullary myelopathy: radiological differential diagnosis for the on-call radiologist. Clin Radiol 2009;64:84-94.
3. Brasil. Ministério da Saúde. Secretaria de Vigilância em Saúde. Agência Nacional de Vigilância Sanitária. Protocolo de vigilância epidemiológica de eventos Adversos pós-vacinação: estratégia de vacinação contra o vírus Influenza pandêmico (H1N1). Brasília: Ministério da Saúde, 2010.

\footnotetext{
${ }^{1}$ Neurologist of Nathan Portella Tropical Diseases Institute, Federal University of Piauí, Teresina PI, Brazil;

${ }^{2}$ Nathan Portella Tropical Diseases Institute, Federal University of Piauí, Teresina PI, Brazil;

${ }^{3}$ Faculdade NOVAFAPI, Teresina PI, Brazil.

Correspondence: Marcelo Adriano da Cunha e Silva Vieira; Rua São Pedro 2.133; 64001-380 Teresina PI - Brasil; E-mail: macsvieira@superig.com.br Conflict of interest: There is no conflict of interest to declare.

Received 10 January 2012; Received in final form 09 March 2012; Accepted 16 March 2012.
} 